\title{
Лермонтов и Литтелл: семантика повторов
}

Аннотация: При анализе творчества Лермонтова акцент ставится на повтор, который он использует во многих произведениях, и благодаря ему обнаруживает возможности смыслового изменения, перекраивания сюжетных линий, показ жизни вещей и персонажей в свободном состоянии. Анализ трех произведений Лермонтова («Исповедъ», «Боярин Орша» и «Мцыри») показывает, что они составляют единую логическую цепь размыилений, разрывать которую нельзя, не нарушив Лермонтовского замысла: показать предельные возможности не только человеческой души, но самой способности суждения, идея которой завоевывала в это время европейскую философию. Исповедь и суд - основные понятия трех поэм. Анализу подвергается использование «повтора» лермонтовских тем в произведении Дж.Литтелла «Благоволительницы». Статья написана методом сравнительного и ситуационного анализов. Кроме того, была осуществлена проблематизация темы повтора и тождества. Лермонтовские темы сегодня актуальны в связи с проблемой атомизации общества, с проблемой абсолютного - метафизического, а не романтически-сентиментального - одиночества, позволяющего смотреть на мир со стороны, но и с осознанием недоступности, несмотря на полную формальную доступность. Попытки анализировать форму его стихов, количество стоп в ямбах и пр. совершенно несостоятельны.

Ключевъе слова: Повтор, исповедъ, молчание, созерцание, свобода, тюрьма, нацизм, смысл, эквивокальность, герменевтика.

Review: When analyzing Lermontov's creative work, the author of the article focuses on repetitions often used by Lermontov. Such repetitions allowed Lermontov to discover the opportunities of conceptual changes, to change his story lines and demonstrate the life of things and heroes. The results of the analysis of the three poems written by Lermontov (Confession, Boyarin Orsha and the Novice) prove that these poems constitute a single chain of Lermontov's thoughts on uttermost possibilities of not only human soul but also the thinking ability in general, the topic that was so popular in the European philosophy of those times. Confession and judgment were the main concepts discussed by Lermontov in those three poems. The author of the present article also examines the 'repetition' of Lermontov's topics in Jonathan Littell's 'The Kindly Ones'. The article was written based on the methods of the comparative and situation analysis. In addition, the author has performed the problematization of repetition and equation. The topics discussed by Lermontov grow especially important today as a result of social automization and absolute, i.e. metaphysical but not romantic or sentimental, loneliness that allows to look at the world from the outside but at the same time makes it inaccessible despite its visual accessibility. According to the author, it is useless to analyze the form of verses and the number of syllables in iambs and etc.

Keywords: Repeat, repetition, confession, silence, contemplation, freedom, prison, Nazism, meaning, equivocality, hermeneutics.

1

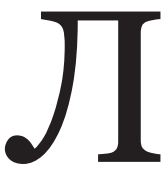
ермонтовские темы сегодня актуальны, как никогда.И не только в связи с проблемой атомизации общества, с проблемой абсолютного - метафизического, а не романтически-сентиментального - одиночества, позволяющего смотреть на мир со стороны, но и с осознанием недоступности, несмотря на полную формальную доступность. Иногда кажется, что попытки анализировать форму его стихов, количество стоп в ямбах и пр. совершенно несостоятельны. Лермонтов словно нарочно пишет привычным стихом, поскольку и привычный его стих не всегда достигает слуха, не дослушивается, не прочитывается. Даже В. Розанов считает его православным - пророком, т. е. человеком, видение которого направлено в будущее. А какое будущее грозит человеку, написавшему «Уж не жду от жизни ничего я, // И не жаль мне прошлого ничуть»? Как написал один из авторов книги «Фаталист. Зарубежная Россия и Лермонтов: из наследия первой эмиграции», «так может писать человек уже умерший, похороны которого почему-то запоздали». Может быть так, а может, здесь гораздо более серьезное местонахождение поэта.

В эпоху Возрождения появились живописные произведения, где Мадонна изображена 
со старым Младенцем, у которого глаза, которые видят насквозь. Этот младенец не в могиле - он, как и Лермонтов, хотел бы забыться и заснуть «не тем холодным сном могилы, // Я б желал навеки так заснуть, // Чтоб дыша вздымалась тихо грудь...» Это очевидно не покойник, запоздали его похороны или нет. Это человек, главная цель жизни которого мысль. Он действительно «знал одной лишь думы власть». Власть не рассудка, а именно мысли. И эта дума связана со свободой, которая понимается как покой, тишина, молчанье, любовь и - как «я», участвующий в этой жизни мысли, глядящий, видящий именно потому, что мыслит. Так определяли свободу все философы, тем более первые любомудры, видевшие исток философии в поэзии. Лермонтов учился или хотел учиться на нравственнополитическом факультете Московского университета, окончить который ему помешали генеалогические затруднения.

Связь с философией очевидна. В повести, носящей условное название «Вадим», писавшейся в начале 1830-х годов, фактически юношей, Лермонтов употребляет именно философские выражения, которые читаешь не без легкой улыбки, потому что сказанное относится к образам или характеристикам молодых персонажей: «... слишком привязавшись к мечте, мы теряем существенность», «разверну все мое существование», «твердое намерение человека повелевает природе и случаю», «первая минута самопознания», «не понимал определения красоты», «сладостьбытия». Немногие исследователи отмечали философские помыслы Лермонтова. Пинский свидетельствовал его связь с Ф. Шеллингом, иные с С. Кьеркегором, Ж.-Ж.Руссо, А.И. Герценом, А.-О. Барбье, В.Гюго и пр. Я сама писала о том, что он был провозвестником нигилизма в России. Но нигилизм здесь не отрицание, а признание истока. Да и итог сравнения несравненен: из Лермонтова, кроме Лермонтова, нельзя вывести ничего и можно вывести все. Это действительно чисто философскипоэтическое начало, которое высвечивается только в его время - на все времена. Он сам по себе, он всегда другой, о чем он заявил прямо и недвусмысленно. И дело не в Байроне, о чуждости которому он говорит, а в том, что он, изгнанник, странник, «чудак» («Валерик»), «ничтожество» («Монолог»), на деле «неведомый избранник», он «или бог - или никто». Это богоизбранничество совершенно особого рода, очевидно, не христианского, ни православного, ни католического типа. Им движет чистая мысль, он постоянно говорит о свершениях ума усилием платонически понятой мысли.Обмысливающий мир subspeciesfinis, он обращен к началу, как к поэтическому истоку мысли и как дару. Его поэзия - не понимание поэзии только как небесного жара, а выражение через поэзию своего «свободного ума», чуждого и небесам («Безумец я! вы правы, правы!»). Он в стороне и от земли, и от неба. Это черная дыра, где все и ничто вместе. Тот ноль (никто и ничто), из которого не выходит ничего, кроме обычно-обыденных выражений. Потому бессмысленно искать у Лермонтова поэтически новизну (особые ямбы и хореи). Его поэзия стара, как мир, нова его полная другость, или чужесть. Жестко оценивая мир, в котором рожден, не питая иллюзий и надежд, отторгая его от себя, он все же по старинке поэзию считал единственной «властью, которой свет внимал в немом благоговенье», а стих «божьим духом», для которого находил одно сравнение - с кинжалом («Поэт»).

Путь к этой поразительной одинокости (не хочется говорить - солипсизму, слишком горделиво навязывающего свое одиночество как нечто высшее) показал Парменид, порекомендовав Сократу «поупражняться побольше в том, что большинство считает и называет пустословием; в противном случае истина будет... ускользать» [1, $135 \mathrm{~d}]$. Лермонтов это пустословие называет «милыми сплетнями», без которых «скучен этот город, с его туманом и водой!..» («Примите дивное посланъе»). Лишь предположив и проанализировав все «да» и «нет» вещей, можно «отвергнуть блуждание мысли» и возвыситься до состояния, где «конец и начало образуют предел каждой вещи», где только беспредельно единое само по себе [1, 135 с, 137 d]. Эти досократические мысли, неважно, знал о них Лермонтов или нет (это лишь доказывает жизнь этих мыслей самих по себе), согласуются с его постижением того мгновенного состояния, о котором можно сказать, что «вечность - ничто перед ним» («Мгновение мы были вместе»). Только дар мысли обеспечивает полноту этого одиночества. Платонов Парменид, кстати, тоже говорил о даре мысли, помогающем «понять» сущность вещи и сущность саму по себе, доискаться до этого и «разъяснить другому» [1, 135 b]. 
Подобная близость свидетельствует о том, что философия всегда современна и своевременна, о чем свидетельствует совпадение не столько позиций, сколько размышлений, попаданий в начало. Такое попадание и обеспечивает повтор, к которому Лермонтов прибегал часто и осознанно. Именно дар мысли не позволяет, а заставляет нечто разъяснять другому любым доступным образом. Повторение - не только мать учения, я меньше всего сейчас хотела бы обращать на это внимание. Повтор заостряет не только поставленную проблему, он провоцирует понимание, он способствует изменению направления движения мысли, он усиливает вес мысли.

В книге «Точки на зрении» [2] я писала о том, как Лермонтов использует одну и ту же тему и один и тот же сюжет (на примере «Маскарада» и «Арбенина») для выражения разных возможностей их развития. Сейчас я хотела бы обратить внимание на дословные повторы в трех произведениях с разными сюжетами, но с одним и тем же исходом: «Исповедь», «Боярин Орша» и «Мцыри».

Прежде, чем предъявить сами повторы, нужно заметить, что эта тема последние несколько десятилетий носится в воздухе. Даже не говоря о том, сколько появилось книг, ей посвященных (довольно упомянуть «Повторение» С.Кьеркегора и «Различие и повторение» Ж.Делёза), можно вспомнить о событиях в области образования, давшей нам бесчисленное количество повторов в студенческих работах, в которых списывание с книг или статей, полученных через систему интернета, стало обычным делом, несмотря на угрозы проверок, осуществляемых с помощью «антиплагиатных» программ. Дело не только в промахах образования, дело в полной смене философских и научных ориентиров: антигегелевский пафос отрицания тождества задал акцент на онтологическое различие (М.Хайдеггер), которое стало центром притяжения и сугубо абстрактных размышлений и технологических разработок. У Лермонтова, современника Кьеркегора (тот был годом моложе), повтор обнаруживает возможности перекраивания сюжетных линий, показ жизни вещей и персонажей в свободном состоянии, оказывающихся настолько по ту сторону «антропологических предикатов», что человек (философ, стихотворец, романист) открывает через свое послание, о котором Лермонтов говорит, что оно не «послание Павла», но нечто «более глубокое, чем время и вечность».
Можно вслед за Делёзом сказать, что то, откуда что-то начинается, вневременно и вневечно и апокалиптично [3, с.11], но у Лермонтова, который считает себя богом или никем, оно очевидно не безлично. Он, как и Делёз, составляет, переделывает персонажей, их понимание и понятия, события, дифференцирует их, делает из повторов нечто новое, переводит знание в незнание, делает повтор «высшим объектом воли и свободы» [3, с.18] и определяет современную мысль как деянье, как «работу голове» («Валерик»). Чем не похоже на российское событие 1993 г. (расстрел парламента) описание «сшибок» в «Валерике»: «Мы любовалися на них, // Без кровожадного волненья, // Как на трагический балет», приходящее в столкновение сцены и уникальной судьбы: «зато видал я представленья, // Каких у вас на сцене нет». Названия его стихотворений часто исходят из осознания двойственности (эквивокальности, дву-о-смысленности) сознания, возможного лишь тогда, когда оно безразлично-отстраненно (а Лермонтов странник) к природным законам, но эта отстраненность дает о себе знать только при восстановлении или воображении этих законов, которые даны в силу того, что оно в них помещено фактом рождения. «Звуки и взор», «Земля и небо» - в этих стихах вневременное (вне времени и вечности) существование он называет по старинке «мигом» или понятным «другим, которое роднится с душой, но это несравненное другое, то, что в свое время Николай Кузанский назвал «Неиным».

Итак, вот три произведения, из которых редакторы И.Л. Андроников, Д.А. Благой и Ю.Г. Оксман в четырехтомнике 1957 - 1958 гг. выделили «Мцыри» как лучшее, а «Исповедь» и «Боярин Орша», как несовершенные, юношеские. Во втором томе редакторы сделали две одинаковых рубрики: «Поэмы и повести в стихах». Первая и главная охватывает только 1837-1841 гг., а вторая - 1828-1836. Они полагали (или делали вид, что полагали) принцип строгой хронологии механически понятым. В предисловии к изданию, названном «От редакции», написано, что этот принцип привел к тому, что напечатанные в массовых изданиях произведения 1828-1836 гг. находятся «в разительном несоответствии с интересами широкого читателя», что они якобы «заслоняют высшие достижения гения Лермонтова» [4, т.1, с.5]. Писали серьезные мужи о маленьком и очень молодом Михаиле Юрьевиче. Но так ли уж они правы? Что повторено в этих 
произведениях, отделенных друг от друга пятилетиями («Исповедь» написана ок. 1831 г., «Боярин Орша» - в 1835 г. и «Мцыри» - в 1840 г.) [4, т.2]?

Во всех трех произведениях есть строки:

«Ты слушать исповедь мою // Сюда пришел, благодарю» («Исповедь», с. 232, «Боярин Орша, с. 369, «Мцыри», с. 52) ${ }^{1}$;

«Меня могила не страшит:// Там, говорят, страданье спит// В холодной вечной тишине; // Но с жизнью жаль расстаться мне. // Я молод, молод, знал ли ты, // Что значит молодость мечты? (вариант:Разгульной юности мечты?) // Или не знал, или забыл, // Как ненавидел и любил; // Как сердце билося живей // При виде солнца и полей // С высокой башни угловой, // Где воздух свеж и где порой // В глубокой скважине стены, // Дитя неведомой страны,// Прижавшись, голубь молодой // Сидит, испуганный грозой? // Пускай теперь прекрасный свет // Тебе постыл: ты слеп (вариант: слаб), ты сед, // И от желаний ты отвык. // Что за нужда? ты жил, старик!// Тебе есть в мире что забыть, // Ты жил, - я также мог бы жить!» («Исповедь», с. 231 - 232, «Боярин Орша», с.373, «Мцыри», с.54); Что здесь? Сомкнулись старость и молодость, но это не повтор, а чистое различие. Тот жил, а этот нет. Чистое отрицание, но в Мцыри хвала свободе, в исповеди - опора на «нет», не я. Иная акцентировка одного и того же.

«Я человек, как и другой» («Исповедь», с. 233; «Боярин Орша», с. 369); тема равенства.

«Пусть монастырский ваш закон // Рукою неба утвержден, // Но в этом сердце есть другой, // Ему не менее святой; // Он оправдал меня - один // Он сердца полный властелин; // И тайну страшную мою я неизменно сохраню» («Исповедь», с. 232; «Боярин Орша», с. 369); Тайна: не выдать имени возлюбленной, в Орше: не выдать соратников. Но в «Исповеди» - наиболее в этом отношении мощной - противопоставлены свобода и жизнь: «я волен... я не брат живых».

«И ты, бесчувственный старик (вариант: «и ты, и ты, слепой старик»), // Когда б ее небесный лик // Тебе явился хоть во сне, // Ты позавидовал бы мне // И в исступленье, может быть, // Решился б также согрешить, // Отвергнув всё, закон и честь, // Ты был бы счастлив перенесть // За слово, ласку или взор // Мое страданье (вариант: «мученье»), мой позор!..» («Исповедь», с. 233 - 234; «Боярин Орша», с. 369)

${ }^{1}$ Ссылки в скобках на: Лермонтов М.Ю. Соч.: В 4-х т. Т. 2.
«Я б вырвал (вариант: «я вырву») слабый мой язык» («Боярин Орша», с.372; «Мцыри», c.62).

«Не говори, что божий суд // Определяет мне конец: // Всё люди, люди, мой отец» («Исповедь», с.231; «Боярин Орша», с.373).

«...тот, кто [крик сей] услыхал,// Подумал, верно, иль сказал, // Что дважды из груди одной // Не вылетает звук такой» («Исповедь», c. 236; «Боярин Орша», с. 363).

«Душой дитя - судьбой монах (в «Мцыри» через запятую, без тире. - C.H.). // Никто не смел мне здесь сказать // Священных слов: “отец” и “мать” (в «Мцыри» синтаксис другой, более нарративный, без останавливающего двоеточия. - C.H.)» («Боярин Орша», с. 370; «Мцыри», с.53).

Этого довольно для того, чтобы понять, что повторы - и повторы серьезные - производились Лермонтовым намеренно и осознанно: при всей событийной разности произведений в них было нечто одно, и тоже весомое. Эти повторы не только дают понять то, что ныне наиболее востребовано (см. выше), но и показывают способ изменения мысли, сюжета, характера самого персонажа. Так, смена наклонения в стихотворной фразе («Я б вырвал грешный мой язык» на «Я вырву слабый мой язык» свидетельствует о том, что одни и те же слова могут быть вызваны разными мотивациями, способными изменить все поведение человека: в первом случае в «Боярине Орше» речь идет о мотивации, связанной с честью и достоинством героя, когда он не должен выдать имена товарищей-разбойников, во втором - мотив чисто психологический: гордость, не позволяющая Мцыри просить помощи у кого бы то ни было. Такой повтор, делающий воображение (перед нами повести, рассказы) продуктивным и вместе с тем мнимым (могло бы случиться так, если бы я...), намечает путь к творческой манере Х.Л.Борхеса, написавшего рассказ «Пьер Менар, автор “Дон Кихота” , в котором вымышленный писатель полностью буквально воспроизвел текст Сервантеса, который в то же время оказался другим текстом из-за разности восприятия и понятийной смены значений слов: мироощущение Пьера Менара пересилило тождество текста, сделав его другим. Когда, например, Менар, повторяет точь-в-точь слова Сервантеса об истории как матери истины, он под исторической правдой понимает не то, что произошло, а то, что мы считаем происшедшим. Борхес замыслил через Менара передать свое отношение к по- 
втору как палимпсесту, позволяющему различить на стертом пергаменте изначальные смыслы. «Мыслить, анализировать, придумывать... это не аномальная деятельность, а нормальное дыхание разума», - писал он за своего персонажа. То же и Лермонтов: он показывает полную эквивокальность не одного слова, а целого законченного высказывания. «Так что у них двойное существование, в идеальном двойнике - чистое повторение старого и современного текста, одного в другом» [3, c.12], или одного через другой, вопреки другому (например, текста «Исповеди» в «Боярине Орше» и «Мцыри» или текста «Исповеди» только в «Боярине Орше», или текста «Боярина...» в «Мцыри»). И тогда оказывается, что повтор - не общность, а сила, связанная с переключением мысли. Он - своего рода проверочные слова, манок: кто и как откликнется, и тогда проступает - как следствие повтора - такая глубина, про которую только и можно сказать: бог или никто.

Гораздо серьезнее, что повторы применяются в произведениях, отмеченных единством места и действия при разности сюжетов. Действия во всех трех поэмах разворачиваются главным образом в монастыре. В «Исповеди» речь только об исповеди осужденного на казнь человека, видимо, за совращение девицы. В «Боярине Орше» разворачивается длинный сюжет со сказочным зачином-намеком на преступную любовь двух молодых людей, которых в результате понявший намек отец застает вместе, запирает дочь на ключ, бросив ключ в реку, а юношу отдает в руки монахов, учреждающих над ним суд с пристрастием. Юноше удалось, распилив решетку, бежать, затем участвовать в боях на стороне Литвы, сражаясь против отца своей любимой. Раненый боярин сообщает ему о страшной участи своей дочери и, приказав «скакать» к ней, вероятно в полном помрачении ума, поскольку с момента, как он запер ее, прошел не один день, умирает. А юноша, прилетев к любимой и застав ее на ложе смерти, понимает, что все же казнь над ним свершилась, хотя и не равная, как он считает, его вине. Во всех трех поэмах, таким образом, два главных для понимания действия персонажа: юноша и старец - при общем героическом пафосе произведений. Действие разворачивается близ рек: Гвадалквивира, Днепра, Арагвы и Куры - символах раздолья и воли. Шум рек, молчанье природы и таинственность монастырей - тот фон, на котором разворачива- ется основное действие поэм. На этом сходство кончается. Все остальное - разное.

Старец в «Исповеди» и «Мцыри» - монах. О старце «Исповеди» ничего не известно, кроме того, что он принял исповедь у осужденного на казнь, старец-монах из «Мцыри» - внимательный слушатель. В «Боярине Орше» - боярин-злодей и коварный монах-судья, выпытывавший тайну юноши - два как один.

Юноша в «Исповеди» - «отшельник молодой, испанец родом и душой», в «Боярине Орше» - бывший «раб», которого спас некий монах (как и Мцыри), выросший в монастыре, «душой - дитя, судьбой монах», убежавший, как и Мцыри, из монастыря, «боязнь с одеждой кинув прочь», стал разбойником. Кто издал тот крик изумления, который дважды не вылетает из одной груди, из поэмы неясно, но издать его мог и тот, кого застали в комнате дочери боярина, бывший раб, невольно проговорившийся, что стал разбойником, и сам боярин, пораженный сословной неразборчивостью, как ему казалось, дочери. Мцыри неслужащий монах, может быть, послушник. Из троих имя имел только один - разбойник Арсений. Повторы подчеркивают различия в характерах и поступках героев при настойчивом стремлении к воле и свободе, усиленной свободой воли. Смыслы повествований также разные, хотя все поэмы скреплены некой тайной. В «Исповеди» - смысл в любовном преступлении и в тайне, которую хранит узник, не желая назвать имени возлюбленной; в «Боярине Орше» - в любовном преступлении, нарочито в суде замещаемом и подменяемым государственным (разбой), а затем действительно становящимся таковым, когда герой начинает сражаться не на стороне России (повесть Н.В.Гоголя «Тарас Бульба, кстати говоря, была написана в том же 1835 г., когда был написан и «Боярин Орша»). В «Мцыри» - вообще нет преступления, чистое желание свободы, оборачиваемое вечным возвращением в монастырь. Круг этот пугающ: «Я думал это страшный сон» (с. 65).

В «Исповеди» дело кончается казнью героя, в «Боярине Орше» - бегством от казни, снова замещенной и подмененной умерщвлением возлюбленной. В «Мцыри» вообще речи о казни нет. Там - чистая героика: схватка с барсом возвеличена гордостью («что быть бы мог в краю отцов не из последних удальцов». Если иметь в виду участь героев, то «Боярин Орша» оказывается трансгрессивным произведением, обнажающим процедуру перехода одного в другое. Им оказывается дискурсив- 
ный обмен-подмена, позволяющая совершить уже не дискурсивную, но реальную подмену (реальное предательство), в свою очередь при ментальном очищении переводящееся при включении осознания поступка в ментальное очищение. Таким образом, «Исповедъ» - «Боярин Ориа» - «Мцыьри» составляют логическую цепочку размыцилений, разрывать которую нельзя, не нарушив лермонтовского замысла: показать предельные возможности не только человеческой души, но самой способности суждения, сама идея которой завоевывала в это время европейскую философию, тем более, что и исповедь, и суд как таковой оказывается главными понятиями всех трех поэм.

Это первое.

Медленное созерцание («дрожащих огней печальных деревень») - второй принцип, подобный обстоятельному доискиванию, а затем разъяснение другому через голос (крик, звон, речь, голосок, язык). Голос - основной термин его поэзии, разом находящий отклик (как повтор) почти во всей русской литературе: в «Исповеди» после казни героя некая обворожительная монахиня в дальнем монастыре издала «слабый крик», который «пролетел и вмиг утих», однако его услышала героиня «Путешествия дилетантов» Б.Ш.Окуджавы, который, конечно же, не случайно сделал Лермонтова тайным его героем. Лермонтов ломает все устоявшиеся представления считать его романтиком. Считает, к примеру, Розанов «Мцыри» чистым романтизмом, а эпиграф к «Мцыри» взят из 1 Книги Царств, «Боярин Орша» с эпиграфами из Дж. Байрона на деле являет собою «песенный» жанр, подобный «Песни о купце Калашникове» или «Песни о вещем Олеге («я узнаю...улыбку прежнюю твою и в ней шипящую змею», с. 379).Если в «Мцыри» есть намек на эпос «Витязь в тигровой шкуре», то в «Боярине Орше» кивки в сторону того же А.С.Пушкина (например, сказка Сокола: «их вместе в бочку засмолить и в сине море укатить»), народных сказок («жил-был за тридевять земель», с. 360), исторических легенд (Арсений ушел в ляхи - очевидный намек на историю Лжедмитрия), семейных преданий, о чем свидетельствуетимя героя «Боярина Орши» - Арсений (поворот в сторону фамилии бабушки - Арсеньева, даже в игровое состояние нашей современности: «он в цепи существ давно едва ль не лишнее звено» (слабое звено). И не боярин Орша - главный ге- рой «Боярина Орши», а Арсений: Лермонтов устроил маскарад в собственной поэме.

Третье. Речь у него идет не о православиикатоличестве и вообще не о христианстве, не (в других произведениях) мусульманстве или иудаизме, поскольку эти конфессии - дела людей, разделенных, условно говоря, территориально-идеологически. Речь о чисто философской, вне- и по-ту-стороннем (постороннем) помышлении концов и начал. У Лермонтова - не забудем и напомним - монастырь - тюрьма. «Вернулся я к тюрьме моей», говорит Мцыри (с. 65), называя себя «в тюрьме воспитанный цветок» (с. 66). Исповедь (всегда произносящаяся на краю смерти) здесь предполагает своего рода нигилистическое освобождение. Осужденный на казнь испанец, сидя «в монастырской тюрьме» (с. 230) говорит на исповеди: «Я, свежий, пылкий, молодой, // Который здесь перед тобой. // Живу, как жил тому пять лет, // Весь превращуся в слово “нет”! // И прах, лишенный бытия, // Уж будет прах один - не я» (с. 233). К христианскому мировоззрению с его представлением о смерти как рождении к новой жизни это отношения не имеет. То же в «Боярине Орше»: «здесь прах ее, но не она» (с. 385). Это чистая философия небытия, которое представить так же трудно, как и бытие, согласно тому же Платонову Пармениду. Тем более, что и одно из важных для христианина дел - писанье фресок - представляется «как жалкий труд, // Отнявший множество минут у бога, дум святых и дел: // Искусства горестный удел» (с. 366).

Разумеется, выбор места действия - монастыря как предельного иночества, важен для Лермонтова-мыслителя, чтобы решить (выяснить, поставить) важный для того времени, для России вопрос: «для воли иль тюрьмы на этот свет родились мы» («Боярин Орша», с. 371). Вопрос о свободе - роковой вопрос, лишающий смысла попытки отстранить Лермонтова от авторства стихотворения «Прощай, немытая Россия», равно как и прописывать его по области романтизма. Свобода - это свобода всего и от всего, свобода не отвечать на призыв и приглашение. В такой свободе сам разум отшатывается от предельного рационализма, ему приходится начинать что-то делать там, где еще ничего нет, где все молчит. Этим, вероятно, можно объяснить поразительную у Лермонтова странную любовь к отчизне - за «ее степей холодное молчанье, ее лесов безбрежных ко- 
лыханье, разливы рек ее, подобные морям». Эти слова могут служить подтверждением тезиса, будто речь идет о тождестве понятий страны и пространства. Сейчас, когда мы пытаемся - в свете новых территориальных приращений («Крым наш») и в свете попыток обосновать наше величие (когда на неведомых основаниях заговорили о сакральности Корсуни-Херсонеса) - понять, что такое патриотизм, родина и естественное право ее любить, можно допустить такое тождество. Однако Лермонтов, говоря о степях и лесах, вовсе это пространство не сакрализует, как соответственно не сакрализует и власть предержащих. Что он говорит? Он говорит, что рассудок отказывается от жизни, основанной на мифологии (он не победит «ни славу, купленную», заметьте, «кровью», ни темной старины заветные преданья»). Только его личное внимание, обращенное на что-то великое ли, малое (на «разливы рек... подобные морям» или «на пляску с топаньем и свистом под говор пьяных мужичков») делает осмысленным патриотизм и понятие патриотизма. Более того, он обращает внимание на то, над чем мы до сих пор словно не задумывались: он любит - молчание («но я люблю - за что, не знаю сам, - ее степей холодное молчанье». Это особенно надо заметить сейчас, в пору нашего отрицания собственной философии. Она противопоставлена Логосу, он не главное в ней. Она, наша философия - в Молчании (заданной исихазмом), которое, разумеется, нельзя понимать, как животную бессловесность. Русская философия живет проговариванием тишины, вообще дарованной поэту и его слуху.Слова тишины не случайны, как правило, их мало, потому что они - тени молчания. Я даже думаю, что мы иногда отдаем философию на откуп литературе не потому, что она (Достоевский, Толстой) ставит философские проблемы (разве не ставит их живопись?), а потому, что в глубине души понимаем эту природу слов - быть тенью Молчания. Не случайно иногда вменяем в вину Достоевскому некую суетливость, замешанную на внутренней разноголосице, и не случайно М.М.Бахтин прятал себя под этой разноголосицей.

Понимание Лермонтовым пространства связано с простором, предполагающем шум голосов и, в конечном счете, его исключающим. Простор - в молчании при тесноте застревающих в горле слов, смыслов этих слов. Простор удивляет и изумляет, заставляя вы- йти из себя (из обыденного ума, которым, как считается, наделено такое животное, как человек). Молчание - принцип, подобный Парменидову пониманию. Оно - за пределами национальных сходств и различий, за велениями государственных уставов, на которые можно просто махнуть рукой. Это действительно «странная любовь», на которую осмеливается странник, всегда становящийся чужаком. Он противопоставлен всем самодержцам мира именно потому, что он мир не держит, а отпускает на свободу. Но именно он вправе говорить «отечество», не путая его, по слову М.Е.Салтыкова-Щедрина, с «Вашим Превосходительством». И если Пушкин противопоставил фигуры Поэта и Царя как самодержцев мира, то Лермонтов противопоставил империи - свободу, включающую в себя все противоположности мира и заставляющую сделать перебор всех возможностей, испытать их на прочность. Может ли такая позиция завоевать массу? Скорее всего, нет, ибо масса стремится к сохранению стабильности.

\section{2}

Поэма «Боярин Орша», юношеская поэма, проба пера, сегодня актуальна, как никогда, поскольку ставит вопрос о самоосознании, о чести и подлости, о жизни и смерти, о патриотизме как собственном волеизъявлении, т.е. о соотношении «мыслящего я», и патриотизме как аналоге сверху направляемой традиции. Недавно вышел нашумевший роман Дж.Литтелла «Благоволительницы», в котором подчеркивается разного рода литературная перекличка, в том числе с Лермонтовым. Речь в романе идет о нацизме, нацистах, которые решали задачи, связанные с уничтожением людей не просто по доброй воле, но в полном согласии с совестью. Главный персонаж, доктор-юрист Максимилиан Ауэ, нацист, действовавший во время Второй мировой войны на Кавказе, после ссоры с коллегой, который вкладывал в уничтожение евреев, как ему казалось, слишком много страсти, превращая работу в садизм, вызывает его на дуэль. Дело было в Кисловодске, и дуэль должна была происходить на горе Машук. И доктор получает известие о том, что противник намерен мошенничать.

Совершенно очевидна связь этой сюжетной линии романа, написанного в 2006 г. по-французски и переведенного на русский в 2012 г., с Лермонтовым, с лермонтовским «Ге- 
роем нашего времени» (врач-секундант, боевые действия, жульничающий соперник), да и с другими его произведениями, в том числе анализируемыми нами. Доктор Ауэ, как и Печорин, принадлежит к интеллектуальной элите, его IQ очень высок, как и Печорин офицер, т. е. служит), одинок, испытывает скуку при общении с людьми. Герой Литтелла вспоминает приезд в Пятигорск, реквизицию дома отдыха «Лермонтов» описываемые в «Герое нашего времени» Елизаветинскую галерею, места встреч Печорина с княжной Мэри и Верой, радостно удивляется, что здесь живет родственница поэта Евгения Акимовна Шан-Гирей, совершает поездку к месту дуэли Лермонтова, высказывает свои соображения о двух великих русских поэтах, идет в музей и квартиру Лермонтова и подробно описывает и музей, и квартиру, ко всему прочему он еще и знаток греческого, словом, обнаруживает себя образованным человеком, который озабочен научными проблемами своего собеседника. «Скажем, у меня есть время для науки, - рассказывает он о своем пребывании на Кавказе. - В прошлом месяце я обследовал Пушкинскую библиотеку в Краснодаре и наткнулся на интереснейшие вещи. В основном исследования о казаках, но, кроме того, я отыскал грамматики кавказских языков и редкие труды Трубецкого. Меня скоро откомандируют в Черкесск, а там наверняка найдутся книги об адыгах и карачаевцах». Его собеседник замечает: «Член СД, цитирующий Тертуллиана, а не Розенберга или Ганса Франка, - это необыкновенно приятно». И дальше речь идет о переводах из Тертуллиана. Возникает впечатление, что речь идет о встрече двух интеллектуалов. Поразительный эффект романа заключается в том, что в нем через запятую повествуется о проведении расстрелов евреев и других карательных акций.

Литтелл намеренно напоминает о параллелях между прошлой и настоящей литературой, считая это совершенно реальным состоянием, поскольку любая действительность дана через литературу. То, что, помимо Лермонтова, Литтелл кивает на Ханну Арендт, Эсхила, Достоевского, Толстого, Эко, Пушкина, Сервантеса, Василия Гроссмана, Блока, Набокова, Берроуза и других авторов, свидетельствует, что Лермонтов нашел прямой путь в современность. Страшная ирония состоит в том, что все это происходит при проведении акции уничтожения, или эвакуации (слово из романа, но о таком замещении слов «рас- стрел» или «ликвидация» я писала в книге «Философские одиночества») евреев. В романе явно намечена параллель между этой эвакуацией и войной с чеченцами, в которой участвовал Лермонтов. Ужас подобных уподоблений подчеркивается чередованием упоминаний о мирных прогулках, питье минеральных вод, обедах и жестких описаний уничтожения евреев. Разрыв между образованностью героя и ужасом совершаемых им деяний является одним из важных приемов романа. И я не думаю, что упоминание о разговоре Ауэ с «человеком почтенных лет, в хорошем костюме, в очках и с усиками» свидетельствует о том, что Литтелл - защитник Ауэ, пытающийся встать не над, а рядом с эйхманами», как считает Тарн. Дискурсивные разрывы - важнейший осознанно используемый прием. Я думаю, что он не дает оценки этому эпизоду потому, что выше оценки, чем содержащаяся в самом эпизоде, нельзя оставить: молчание главное мотив повествования. Эпизод таков: упомянутый почтенный человек с маленьким мальчиком на руках на прекрасном немецком языке обратился к Ауэ: «Герр офицер, могу я вам кое-что сказать?» - «Вы отлично владеете немецким», - отозвался я. «Я учился в Германии, - с достоинством, даже с некоторым высокомерием сообщил он. - В некогда великой стране». Наверное, профессор из Ленинграда, подумал я. «Что вы хотите?» - сухо спросил я. Мальчик, обхватив его за шею, смотрел на меня большими голубыми глазами. На вид - года два, не больше. «Я знаю, что вы здесь творите, - невозмутимо произнес человек. Мерзость. Я просто желаю вам выжить на войне, а после и через двадцать лет с криками просыпаться каждую ночь. Надеюсь, что вы не сможете смотреть на своих детей, не вспоминая наших, убитых вами».

Как пишет А.Тарн (Алексей Владимирович Тарновицкий), анализирующий именно ассоциации героя романа с лермонтовскими мотивами, здесь возникает параллельнаяреальность, указывающая уже не на качество единственной реальности, представляющей «господствующую картину мира» а на существующую новую конструируемую (например, в интернете) реальность, в которой живут (гневаются, радуются) многие люди, а потому ныне вопрос «а как оно было на самом деле?» лишен смысла [см.: 5]. Более того, всегда были люди, живущие в другой реальности: история христианства, предполагающая «жизнь после смерти» (ад, рай, божественная реаль- 
ность), появление разного рода утопий начиная со времен оных, тому свидетельство. Тарн ссылается на то, что ранее правдой считался «рассказ очевидца», хотя «приходилось принимать на веру его искренность, или того, кто своими ушами слышал очевидца (хотя тут в уравнение достоверности добавлялась уже производная второго порядка)», на то, что «правда содержалась в учебниках и научных трудах, авторитетность коих базировалась на опросе тех, кто слышал тех, кто слышал очевидцев, а также на документах и вещественных доказательствах», однако "с той оговоркой, что документы и вещи также не обеспечивали полной аутентичности взгляда, ибо подвергались многократной редакции, а то и частичному уничтожению, представляя на суд потомков все ту же, сильно модифицированную интересами рассказчиков выборку» [5]. В свое время, в середине 1980-х годов мне то же самое говорил М.Я.Гефтер, в качестве доказательства приводя лживые самооговоры прошедших ГУЛАГ, и считая, что сейчас гораздо важнее «разговоры на кухне». Да и что может быть весомее таких аргументов, как перекраивание учебников, показывающее способы таких перекраиваний, соответственно исторических фактов.

Лермонтов, разумеется, ни на какие исторические факты не ссылался, он сам был историческим фактом. И вряд ли он ставил перед собою цель конструирования реальности. Но он смотрел на предоставленный ему мир из той метафизической глубины, где все видится в неискаженном документами виде, а значит - не так, как кажется «на самом деле» в том числе и его исследователям. Этим видением вызван, как кажется, и его сарказм, и «плохой характер», и все, что было непонятно современникам, тем более потомкам.

Но Лермонтов - не Печорин, он вряд ли руководствовался консервативной традицией, скорее напротив: показывая, как повтор одного и того же может по-разному действовать при сюжетных сменах, выявляет не просто изнанку консервативности, но и возможности выхода из него через отказ от нее через процедуры камуфлирования мыслей, изменения их смысла, когда говорят одно, а делают другое, опустошая и обесценивая не только повседневный обиход слов, но - шире - само право, в том числе - традиционное.

Почему, однако, у Литтелла возникло желание сравнить доктора Ауэ с Печориным, почему возникли аллюзии с Лермонтовым?
Он пытается показать момент, когда консервативная традиция превращается в жестко тоталитарную, и это ведет не к возможностям камуфляжа или смыслового изменения в том числе политического действия (действие поэмы «Боярин Орша» странно и неожиданно переходит из разряда мирной жизни в кипучую битву, и не абстрактно понятую битву, а конкретную, с Литвой и Польшей). Ауэ в отличие от Лермонтова, который участвовал в войне на Кавказе по долгу службы и, если и убивал кого-то, то в бою, не из ненависти к врагу, убивает в уверенности идеологической необходимости убийства, и совершает это по совести. Собственно, роман - это исповедь, то есть как раз то, что является предметом нашего анализа. Герой - нацист, объяснивший, что «если теперь, спустя годы», он «и решился писать, то в первую очередь для того, чтобы не вам, а себе самому кое-что прояснить». Умное отношение к жизни, позволяющее всегда сделать шаг в сторону, сделать себя вненаходимым, рождает ироническое отношение к ней. Не умное, исключительно рациональнорассудочное прямое следование по усвоенному пути приводит к устрашающим результатам. Как-то Гефтер сказал, что бесстрашное вопрошание себя может открыть фашиста в себе, что «фашизм - не нечто внешнее», он «сопоставлен внутренней проблеме человека, утвержденной от рождения Homosapiens. Эта внутренняя проблема человека в нем живет и разрастается»; «в фашизме есть нечто опережающее разум. Человек в той же степени взращен убийством, как он взращен пробудившимся разумом» [цит. по: 6, с.231]. Эти слова кажутся мне первой (до настоящего времени, когда это стало нормой) попыткой изменить смысл слов.

Однако человек, поскольку обладает свободой мысли, воли, слова, способен остановить этого фашиста в себе, если он там есть, а не просто декламируется (высказывания Гефтера похожи на декламацию, подталкиваемой самолюбованием, но в любом случае похожи на декларирование), вряд ли он опередит мой разум - в этом случае я буду считаться невменяемой. Скорее разум может решиться на убийство и тем самым стать или преступным, или заслуживающим снисхождения в зависимости от намерений или мотивов убийства. Теоретически Гефтер, правозащитник, становится единомышленником Ауэ из романа Литтелла. Тот руководствовался не этическими правилами, «впитанными из всей атмос- 
феры своего индивидуального, семейного, общественного бытия», «живого, естественного, самовоспроизводящегося организма», как о том пишет Тарн, сравнивающий так понятую традицию с языком, поскольку и та, и другой «никак не зависят от наших желаний и предпочтений», а исключительно на правильно выстроенные рассудочные регуляции. Забвение такой неоднозначной, противоречивой, интуитивно понимаемой мотивации, которая на деле абсолютно разумна, делает абсолютно виновными участников разного рода «окончательных решений». Но и Литтелл, вопреки Тарну, говорит об Ауэ, что он виновен (с признания этого начинается роман). Ауэ пишет исповедь не только для того, чтобы что-то уяснить себе и современникам, а чтобы занять досуг - это может быть названо воспоминаниями, но не исключено, что то, что он называет совестью, толкало его на откровения: его «охватывала тревога», он осознавал, что «думать вредно», хотя он считает себя рассудительным. Но под «думать вредно» понимает требования прямого следования рассудку, который не создает нового знания, а лишь систематизирует знание и опыт, желая быть непротиворечивым. Он пишет: «Можно с легкостью систематизировать ваши повседневные мысли: практические мысли, в которых вы сами не отдаете себе отчета, планирование действий и их очередности». Определение не случайно: в молодости Ауэ увлекался литературой и философией. К тому же его преследовал стыд.

Этому человеку удалось то, чего не удалось Лермонтову: полное отстранение от эмоций и чувственности. Лермонтов называл Рафаэля вдохновенным («Поэт»), а для героя Литтелла «красивый юноша, скульптура Микельанджело - без разницы», дыхание не перехватывало. У того произошел разрыв между умом и чувством, у этого все синтезировалось в рассудке, который он сознательно санировал и дисциплинировал: он приводит количество расстрелянных в цифрах за месяц, день, час, иронизируя, что это «отличное упражнение для медитации». Да и только ли в разрыве между умом и чувством дело! Разорвались связи между знанием (коллекцией сведений), которое начали считать объективным, и выводами из рационально-расчетливого суждения: если надо идти прямо, то мне не помешает коляска с ребенком, преграждающая путь. Дело рассудка и комплекс сведений странным об- разом иногда связываются между собой. Ауэ позволяет отождествить себя с Печориным; при этом происходит отбраковка, изгнание из Печорина нелюдоедского сознания.

Тарн считает Литтелла «редкостным подлецом». Если понять отрешенное спокойствие Ауэ за позицию Литтелла, то, возможно, что и так. Но нельзя отождествлять автора и героя. Это не Литтел ведет разговор с евреем-горцем о месте его расстрела. Это он передает гладко построенный рассказ о том, как Ауэ вполне дружески ведет разговор с горцем-евреем по-гречески, ведет его в горы, где ему роют могилу и расстреливают. Причем и беседа, и дело как исполнение результата беседы переданы в одном стилистическом ключе. Это безусловное мастерство Литтелла, это безусловное достижение «постмодернистского» романа: ненавязчиво кивнуть, например, на «Приглашение на казнь» В.Набокова с двойничеством и маскарадностью главных героев этого произведения, все персонажи которого - это «галерные рабы» и марионетки с «прорехой, из которой торчит клок серой ваты». Литтелл, одновременно изображая Ауэ культурным человеком и палачом, использует тот же прием, одновременно откровенно кивая в данном случае на лермонтовские приемы той же маскарадности и двойничества, которых он достигает через повтор. Ауэ полагает, один в один повторяет Печорина, выхолащивая при этом смыслы его существования, превращая его в идеологически заданную фигуру, в приказ, оборачивающийся цинизмом, подлостью, геноцидом. Автор это прекрасно понимает, о чем говорит и название романа: Благоволительницы, Эринии, богини мести, настигающие героя на исходе дней. Суров Тарн и несправедлив. Сейчас на границе войны России с Украиной мы остро чувствуем, как и нас настигают Эринии, подогретые рассказом о бандеровцах. Ощущение, будто иногда в романе нарушаются временные рамки, что свойственно современному роману. Но Литтелл хладнокровно ведет нить повествования в рамках мировой войны середины XX в.

Один из персонажей романа говорит: «Есть три возможных способа восприятия нашего абсурдного существования. Первый демонстрируют массы, hoipolloi, отказывающиеся замечать, что жизнь всего лишь шутка. Вот они и не иронизируют над ней, а работают, копят, жуют, испражняются, блудят, плодятся, стареют, словно волы в упряжке, и подыхают идиотами. Их большинство. Другие, и я в 
их числе, отдают себе отчет, что жизнь - фарс, и имеют мужество смеяться над ней, так поступают еще даосы или ваш еврей. Третьи, и это, если я не ошибся в диагнозе, как раз ваш случай, видят, что жизнь - шутка и страдают из-за этого. Я тут, наконец, прочитал вашего Лермонтова, - и он процитировал по-русски: “а жизнь... такая пустая и глупая шутка” . Ауэ добавил к сказанному: «Ему бы следовало еще приписать: грубая». И добавление выдает его плоскость и пошлость, уплощение мысли. И речь здесь идет не о литературном мире, а о самом что ни есть реальном, о случившемся нацизме с его высшей стадией - Холокостом. Литтелл показывает способ, каким любого человека, автора, философа (Гегеля, Ницше) можно использовать в самых омерзительных целях, достаточно свести некий означенный путь как идеологический, как правильность саму по себе, которой все должны следовать, минуя какую бы то ни было саморефлексию, что и есть пошлость. Не случайно сам Литтелл в одном из интервью вспомнил фразу Жоржа Батая: «У палачей нет языка, а если они говорят, то на языке государства» $[7$, с. 632 - 633]. Об этом напомнил и С.Н.Зенкин в послесловии к книге. Когда Литтелла обвиняют в том, что его герой слишком разговорчив, я бы с этим не согласилась, хотя в книге 900 страниц. Это внутренняя речь самого государства, нынешнего, рядящегося под демократическое, искреннее с массами, потакающее ей, откровенничающее и жестко гнущее свою про́клятую линию.

Литтелл подверг скрупулезному анализу момент постижения идеологической веры, хотя «многие наши так называемые "интуитивные” решения в действительности абсолютно разумны (хотя и не формализуемы при помощи стандартной логической цепочки). Принстонский профессор, специалист по когнитивной психологии Даниэль Канеман (по иронии судьбы получивший Нобелевскую премию в области экономики), называет подобные решения “вторым типом мышления”». Об этом пишет и Тарн. «Подлец» - это герой романа, спокойно констатирующий, что «мы живем в худшем из возможных миров. Конечно, война завершена. Урок усвоен, такое больше не повторится. Но неужели вы и вправду уверены, что урок усвоен? И войны не будет? В определенном смысле война не закончится никогда, хотя, возможно, такое и произойдет, когда упокоится с миром последний ребенок, родившийся в послед- ний день сражений. Все равно, она продлится в его детях, в его внуках. До тех пор, пока постепенно не растратится унаследованное, не сотрутся воспоминания». А Литтелл попытался проанализировать вполне в духе Гефтера возникновение фашизма, увидев его не в опережении разума, а в порождении рассудка и в жесткой мельчайшей детализации процесса убийства, которая (детализация) снимает вину за смерть обреченных на нее. Это свидетельствует о том, что наша жажда деталей, того бога деталей, которого иногда призывают поэты, на деле способна оправдать самое чудовищное преступление. Ауэ рассказывает: чтобы выполнить нацистскую программу «Эвтаназия», «отобранных в соответствии с узаконенными предписаниями больных профессиональные медсестры доставляли в специальное помещение, регистрировали и раздевали; врачи их осматривали и отсылали в камеру; рабочий открывал газ; уборщицы мыли; полицейский заполнял свидетельство о смерти. На допросах уже после войны каждый из них удивлялся: разве я виновен? Медсестра никого не убивала, она лишь раздевала и успокаивала больных, это была ее обычная работа. Врач тоже не убивал, просто подтверждал диагноз, руководствуясь критериями, спущенными высшими инстанциями. Помощник, открывавший кран газа, вроде бы во времени и в пространстве теснее всего соприкоснувшийся с убийством, лишь проделывал техническую работу под контролем начальства и врачей. На уборщиц возложили, пожалуй, самую отвратительную функцию - ассенизацию и дезинфекцию. Полицейский занимался своими прямыми обязанностями, констатировал смерть и отмечал, что соблюдались действующие законы. Ну и чья здесь вина? Всех сразу или никого? Почему рабочий, подавший газ, виноват, а работник котельной, садовник или механик - нет? То же и с прочими моментами нашей грандиозной кампании. Виновен ли стрелочник на железной дороге, направивший поезд с евреями в сторону концлагеря? Он - государственный служащий, двадцать лет переводит себе стрелки и ведать не ведает, что внутри вагонов. И не его вина, что через его стрелку евреев доставляли из пункта А в пункт Б, где их уничтожали. Тем не менее в операции по уничтожению евреев он играет важнейшую роль: без него поезд не добрался бы до пункта Б. То же самое касается и чиновников, реквизировавших 
квартиры для пострадавших от бомбардировок, наборщика, печатавшего уведомления о депортации, поставщика, продававшего СС бетон и колючую проволоку, унтер-офицера хозяйственной администрации, снабжавшего бензином тайлькоманды СП, и Всевышнего, допустившего все это. Конечно, можно определить точные уровни уголовной ответственности, позволяющие одних привлечь к наказанию, а других предоставить суду собственной совести, которая у них вряд ли имеется; гораздо легче составлять законы постфактум». И тогда правы оказываются те, кто стоит на позиции общего, которое до вещи и которое расплывчатое и недостаточно определенное, которое называется в философии реализмом, а не те, кто стоит на позиции существования только единичного. Концептуализм, который ругает Тарн, называя его юродивым, постмодернистским проектом крайнего негативизма, здесь ни при чем. Концептуализм не имеет отношения к негативизму, он как раз помогает постичь связь, сцепку конкретного единичного с расплывчатым общим, устанавливая (в данном случае) степень вины и участия в преступлении.

Как это связано с повтором? Очень просто: повтор здесь работает как зомбирование, то есть манипулирование мышлением и поведением многих людей по заданной программе, то, от чего отталкивался Лермонтов, когда «...пестрою толпою окружен, // Когда передо мной, как будто бы сквозь сон, // При шуме музыки и пляски, // При диком шепоте затверженных речей, // Мелькают образы бездушные людей, // Приличьем стянутые маски» («Как часто пестрою толпою окружен...»). Но и такой повтор оказался подобен маскараду, а заодно противоречит и естественному закону и нравственному [3, с.17].

Что делает Литтелл - подчеркивает банальность зла? Нет, его герой Ауэ признает: «Я не стараюсь доказать свою невиновность. Я виновен». Задача в том, чтобы понять в мирное время, как бы каждый из нас вел себя в военное.Роман не случайно появился сейчас, когда все люди мира предали забвению такое понимание, когда почти утратили силу такие понятия, как свобода воли и поступок, хотя повсеместно идет медленная, тягучая, гибридная война, лишающая человечество памяти, в отсутствие которой государство имеет возможность стать авторитарным, противопоставленным обычному человеку.

\section{3}

Но если Литтелл искусно уплощает и ограничивает мир и мысль симулякра Печорина, доктора Ауэ, то Лермонтов, оригинал оригинала, предполагает, что читатель обязан жить в постоянной напряженнейшейвразумленности, и он обязан (именно обязан, если не хочет слушать затверженные речи бездушных людей) находиться в постоянном переключении. Напомним: мы взяли для анализа три поэмы с основной темой - исповеди и с одним местом действия - монастырем. Две из этих поэм некоторыми литературоведами были отнесены к разряду второсортных. Но на деле они оказываются экспериментальными площадками, на которых разворачиваются, разумеется, авторской волей (не насилующей, а творческой, т. е. открытой) поэтические миры, не параллельные, а перекрещивающиеся.В точках перехода-переключения происходит переозначивание произведений, позволяющее слухозрению смещаться с песенного зачина в реалии странно-страшной монастырской жизни, оттуда на опознание исторических сражений, в центре которых оказываются (молодые ли, старые ли, испанцы, русские, грузины) герои Лермонтова, борющиеся друг с другом не из националистических побуждений, хотя и встречаются определения, вроде «злой чечен», что, однако, означает характерологическую черту «чечена», вполне сравнимую с выражением «злой чеснок». А далее - в метафизику бытия, в средостение жизни и смерти, в описание ничтоженья. Рассказ о разбойничьих действиях Арсения из «Боярина Орши» вполне мог входить в практику исповеди при условии ее добровольности. Точкой переключения оказался вопрос «для воли иль тюрьмы на этот свет родимся мы». Именно после этого исповедъ превращается в допрос. И поскольку Арсений предчувствует такое переключение, то, говоря: «ты слушать исповедь мою сюда пришел», произносит слово «исповедь» иронически. Ошибка - считать, что в поэме «Мцыри» мы видим точный повтор этих слов. Там повтор сродни повтору Пьером Менаром «Дон Кихота»: все значения разные. Повтор есть, потому что и там, и здесь - исповедь, жанр один и тот же, но в «Мцыри» действительно исповедь, происходящая на пороге (естественной) смерти у подножия божьего, то есть праведного, суда, здесь - подобие исповеди, производимое тоже на пороге (насильственной) смерти, и чтобы смертный 
приговор был правдоподобен, то исповедь преображается в допрос на человеческом суде, могущем быть неправедным. Повтор ведет не только к самопознанию, но и к его симулякру. «Не понимаю, что была // У вас за мысль? - мои дела // И без меня ты должен знать» (с. 369). Какие дела? Здесь много ответов. Не исключено, что те, за которые не взяли. Ибо он говорит: «А душу можно ль рассказать?» (там же). Не простая и не легкая эта «исповедь», которую, впрочем, не слушают. Здесь все говорят не о том. Арсений исповедует равенство людей («И под одеждою раба, // Но полный жизнью молодой, // Я человек, как и другой» (там же). А ему вместо исповеди навязывают покаяние, которое вполне может оказаться предательством. И Лермонтов четко и жестко противостоит обесцениванию слов, превращению исповеди-допроса в донос, не только обессмысливающий важнейшую религиозную процедуру, но подменяющий религиозную позицию светской. Церковь-судилище начинает выступать в виде карающего органа мирской власти, т. е. служения не Богу, а кесарю. Подмена происходит внутри самих предельных представлений. Что уж говорить о тех, что сопровождают человека в его каждодневной жизни! Карают за любовь юноши к девушке, но делают вид, что за государственное преступление. В этом смысле чрезвычайно важна заявленная Лермонтовым грамматика камуфляжа. Захваченный врасплох в светлице дочери боярина, схваченный и выданный российской монашеской инквизиции, Арсений в «Боярине Орше» рассказывает о своей жизни, которой руководит воля к свободе. Судья-игумен прерывает исповедь словами: «На что нам знать твои мечты?» (с. 361.Неслыханное для христианина дело!).

В этой трансдуктивной точке Лермонтов дает основание для повторов доктора Ауэ, повторов, лишенных жизненной силы исповеди, но стократ усиливающих силу безрефлексивно принимаемого пути. У Лермонтова же происходит перевод проблемы из одной плана в другой, перевод, обеспечивающий дискурсивный разрыв, ведущий к замещению правового содержания. Естественное право на любовь подменяется даже не позитивным правом, а правом силь. Незаконное присвоение сословного статуса (любовь раба к высокопоставленной особе), т. е. подмена статусов преображается в государственную измену, которую необходимо доказать: «Не для того пред нами ты! // Вдругом ты ныне обвинен,
// И хочет истины закон. // Открой же нам друзей своих, // Убийц, разбойников ночных, // Которых страшные дела // Смывает кровь и кроет мгла, // С которыми забывши честь, // Ты мнил несчастную увезть» (с. 371). Если в исповеди тайна - женское имя, здесь - тайна тайного общества, раскрыть которую значит обесчестить себя («я вырву слабый мой язык», с. 372). В статье Б.Уорфа «Об отношении норм поведения и мышления к языку» рассказываются случаи влияния слов на человеческое поведение. Надпись «пустые бензиновые цистерны» позволяют людям курить возле них, забыв о парах бензина, переполняющих цистерны и являющихся поводом к пожару. Лермонтов показывает не только пары бензина, но сам разгоревшийся пожар слов, поменявших смысл и значение. Ханна Арендт создала своего рода классификацию таких подмен, когда, например, слово «убийство» замещалось «эвакуацией». Но Лермонтов усложняет (двуосмысливает) задачу: он показывает, как одно и то же слово может скрыть разные содержания.

Он переиначивает с помощью повторов сами сюжетные коллизии. В «Боярине Орше» умирает старик, в «Мцыри» - юный инок. Конец перевернул старость и молодость. Тем более, что в «Боярине Орше» был момент, когда смерть уготована одновременно и старцу и юноше: в суде, в предчувствии смертного приговора последний говорит «Обоих нас могила ждет» (с. 370).

К тому же конец поэмы «Боярин Орша» страшное, реальное, вовсе не романтическое явление смерти: «Громаду белую костей // И желтый череп без очей // С улыбкой вечной и немой - // Вот что узрел он пред собой. // Густая длинная коса, // Плеч беломраморных краса, // Рассыпавшись, к сухим костям // Кой-где прильнула...», «приняв другое бытие» (с. 384). Ж.Легоф в XX в. написал книгу «Другое средневековье». Лермонтов за более чем век до него создал «другую литературу», которая осталась неопознанной. Очевидно, что он не мог стать евангельским пророком, как того хотел Розанов. Несоответствие, дискурсивные разрывы ведут к выходу из жизни. Если «Мцыри» можно назвать апологией свободы, не нашедшей выхода и превратившейся в вечное возвращение (Мцыри, бежав из монастыря и блуждая по горам-лесам, вышел к тому же монастырю-тюрьме). Выходом является смерть. Если в «Исповеди» молодой любовник ищет опору в нигилизме, в установ- 
ке на «лишенность бытия» (с. 233), с которой могло бы посоперничать определение зла как лишенности блага, то в «Боярине Орше» прокладывается путь для Печорина, оказавшись не лишним человеком, а человеком, лишенным жизни. Лишней оказалась жизнь: «Иду отсюда навсегда // Без дум, без цели и труда, // Один с тоской во тьме ночной, // И вьюга след завеет мой» (c. 385). Это было написано задолго до «Героя нашего времени», ибо Лермонтов, как его герои, «знал одной лишь думы власть», противопоставленной Жизни.

Итак, повтор, то иронический, то упорно тождественный самому себе, узаконивает жесткую противопоставленность мышления бытию, принимая сторону мышления и действуя вопреки этическим принципам, поскольку речь ведется из тех глубин, где царствует ничто. Бесконечным повтором, меняющим саму жизнь, решается дилемма тюрьмы или свободы. Сама поэзия как один и единственный исток философии становится выражением, как говорил Делёз, «частного размышления». Повторы в этом случае выполняют контролирующую функ- цию, позволяющую проверить некоторое утверждение или некую мысль в других воображаемых или возможностных ситуациях. Потому тема смерти у Лермонтова является результатом непосредственного рассмотрение феноменов, возникающих вследствие повторов. Это очевидно трансцендентальный принцип, задающий эквивокальность знака, обеспечивающую разрывы и нарушения смысла. Подобные нарушения рождают непонимание и вызывают глухоту. Собственно повторы важны для развития слуха. Они направлены к глухим. То, что люди окутаны глухотой, Лермонтов прекрасно понимал. Он писал: «К тебе не домчатся ни слово, ни звук ( ${ }^{*}$ «Печаль в моих песнях...»); «Мои слова печальны: знаю; // Но смысла их вам не понять» («Безумец я! Вы правы, правы!»); и совсем трагическое: «Никто словам моим не внемлет... я один» (там же). Его письмо как на деревню дедушке. И это сознательный прием, свидетельствующий не о грамотности/неграмотности, а о естественном, или, как сейчас говорят, обыденном состоянии слова.

\section{Библиография:}

1. Платон. Парменид // Платон. Соч.: В 3-х т. Т. 3 (1). М.: Мысль, 1972.

2. Неретина С.С. Точки на зрении. СПб., 2006.

3. Делёз Ж. Различие и повторение. СПб., 1998.

4. Лермонтов М.Ю. Соч.: В 4-х т. Т. 1-4. М., 1957.

5. Тарн Алекс. Герой нашего времени. Заметки о романе Дж.Литтелла «Благоволительницы» // Заметки по еврейской истории (http://berkovich-zametki.com).

6. Павловский Г. 1993. Элементы советского опыта. Разговоры с Михаилом Гефтером. М., 2014.

7. Батай Ж. Проклятая часть: Сакральная социология / Пер. Е.Д.Гальцовой. М., 2006.

\section{References (transliterated):}

1. Platon. Parmenid // Platon. Soch.: V 3-kh t. T. 3 (1). M.: Mysl', 1972.

2. Neretina S.S. Tochki na zrenii. SPb., 2006.

3. Delez Zh. Razlichie i povtorenie. SPb., 1998.

4. Lermontov M.Yu. Soch.: V 4-kh t. T. 1-4. M., 1957.

5. Tarn Aleks. Geroi nashego vremeni. Zametki o romane Dzh.Littella «Blagovolitel'nitsy» // Zametki po evreiskoi istorii (http://berkovich-zametki.com).

6. Pavlovskii G. 1993. Elementy sovetskogo opyta. Razgovory s Mikhailom Gefterom. M., 2014.

7. Batai Zh. Proklyataya chast': Sakral'naya sotsiologiya / Per. E.D.Gal'tsovoi. M., 2006. 